\title{
CORROSION PROPERTIES OF 1.4512 FERRITIC AND 1.4404 AUSTENITIC STEELS FOR THE AUTOMOTIVE INDUSTRY
}

doi: $\quad 10.2478 /$ czoto-2019-0095

Date of submission of the article to the Editor: 12/11/2018

Date of acceptance of the article by the Editor: $21 / 12 / 2018$

\author{
Viera Zatkalíková ${ }^{-}$orcid id: 0000-0003-1924-3785 \\ Lenka Markovičová ${ }^{-}$orcid id: 0000-0002-1129-5532 \\ Anna Wróbel-Knysak ${ }^{2}$ - orcid id: 0000-0003-0187-1361 \\ ${ }^{1}$ University of Žilina Slovakia, viera.zatkalikova@fstroj.uniza.sk \\ ${ }^{2}$ Kielce University of Technology, Poland
}

\begin{abstract}
Exhaust systems are susceptible to in-service wear because of their exposition to the very aggressive corrosive environment. Various stainless steels grades (mostly ferritic and austenitic, but also martensitic and duplex) and protective coatings are currently used for exhaust system elements to increase their aestetics and corrosion resistance. This article focuses on evaluation and comparison of the common corrosion properties of two stainless steels with different microstructures (ferritic and austenitic) used for exhaust system components at the low ambient temperature $\left(35^{\circ} \mathrm{C}\right)$. An aggressive acidic corrosion solution for electrochemical cyclic potentiodynamic tests (ASTM G61) was chosen to simulate partly inner (condensate) and also external environment (reaction of exhaust gases with water, chlorides in solution after winter road maintenance). Exposure tests of the pitting corrosion resistance were performed according to ASTM G48 standard method.
\end{abstract}

Keywords: Corrosion, Ferritic stainless steel, Austenitic stainless steel, Cyclic potentiodynamic test, Exposure test

\section{INTRODUCTION}

A technological progress in different industry fields, among others in automotive industry brings high exploational durability requirements of devices and also it is an inspiration to work out on new materials and technologies to protect materials working in aggressive environments. The total elimination of negative effect on corrosive processes on surfaces of devices is impossible however it can be minimized by suitable grade of steel, protective coatings or by the modification of chemical composition and the structure of material (Adamczyk, 2004), (Wróbel-Knysak, 2012), (Lukaszkowicz, 2014).

Exhaust systems exposed to the very aggressive corrosive environment are particularly susceptible to in-service wear. Due to a complex structure of the system, there are service-related factors that affect it especially negatively - variable 
temperature (average cars exhaust fumes at the collector entrance reach over $900{ }^{\circ} \mathrm{C}$, in the front pipe approx. 800-900 ${ }^{\circ} \mathrm{C}$, in the catalytic converter exhaust fumes cool down, in the tailpipe approx. 200-350 ${ }^{\circ} \mathrm{C}$ ), aggressive composition and low pH of condensate and mechanical damage as well. The above mentioned factors depend on the location, operation and maintenance, vehicle capacity and engine type (Han et al., 2014), (Wróbel-Knysak, 2016).

The biggest danger for the exhaust systems is the high temperature corrosion additionally increased by the reaction of the condensate. High temperature corrosion resistance of metallic materials during the operation of the automotive exhausts can be increased by using suitable alloying elements, which inhibit the oxidation processes (for iron alloys: $\mathrm{Al}, \mathrm{Cr}, \mathrm{Ni}, \mathrm{Si}, \mathrm{Co}, \mathrm{Mg}$ ), by using protective coatings or by using different steel grades depending on the operating conditions of the individual exhaust system components (Bala, 2002), (Wróbel-Knysak, 2012), (Lukaszkowicz, 2014).

Material selection of an exhaust system depends on several parameters (e.g. temperature, geographical region and vehicle application) according to the operating conditions of the individual components. Manifolds are mostly made of cast irons, for the mufflers and pipes commonly ferritic stainless steels are used (Rajadurai et al., 2014).

Austenitic stainless steels were used for exhaust systems in previous years (e. g. mufler in Audi 80). The authors (Inoue and Kikuchi, 2003) suggest austenitic stainless steel (316L) for flexible pipes manufacturing.

According to numerous authors (Lukaszkowicz, 2014), (Rajadurai et al., 2014), (Wróbel-Knysak, 2016), (Wróbel and Kucharska, 2011) the most economical solutions for protection and for improvement of aesthetics and service life are hot dip aluminium - silicon coatings deposited on the surface of 1.4512 steel with increased corrosion resistance.

The aim of this paper is to evaluate and compare the common corrosion properties of two stainless steels with different microstructures (ferritic and austenitic) used for exhaust system components at the low ambient temperature $\left(35^{\circ} \mathrm{C}\right)$. An aggressive acidic corrosion solution for electrochemical cyclic potentiodynamic tests (ASTM G61) was chosen to simulate partly inner (condensate) and also external environment (reaction of exhaust gases with water, chlorides in solution after winter road maintenance). Exposure tests of the pitting corrosion resistance were performed according to ASTM G48 standard method.

\section{EXPERIMENTAL MATERIAL}

The experimental material:

- The 1.4404 (X5CrNiMo17-12-2, 316L) austenitic stainless steel (chemical composition according to the manufacturer's certificate in Table 1) was purchased in sheet $(1000 \times 1500 \mathrm{~mm})$ of $1.5 \mathrm{~mm}$ thickness. Its treatment (marked as IIB/IIIC) was based on cold rolling, homogenization annealing $\left(1040-1100{ }^{\circ} \mathrm{C}\right.$ and pickling after slightly smoothing rolling (www.italinox.sk).

- The 1.4512 (X2CrTi12, 409) ferritic stainless steel (group of steel with increased corrosion resistance) in the form of a sheet (1 $\mathrm{mm}$ thickness) after rolling preparing for the application of Al-Si coating in a hot dip process. The chemical composition according to the EN 10088 is presented in Table 1 (PN-EN 10088-2). 
Microstructure of the 1.4404 stainless steel (Fig. 1.) is created by polyedric austenitic grains with numerous twins, which could be created by annealing or by rolling (Uhríčik et al., 2016).

Table 1

Chemical composition of the 1.4404 and 1.4512 stainless steels

\begin{tabular}{|c|c|c|c|c|c|c|c|c|c|c|c|}
\hline & \multicolumn{10}{|c|}{ Content of element [wt.\%] } \\
\cline { 2 - 11 } & $\mathbf{C r}$ & $\mathbf{N i}$ & $\mathbf{M o}$ & $\mathbf{M n}$ & $\mathbf{N}$ & $\mathbf{C}$ & $\mathbf{S i}$ & $\mathbf{P}$ & $\mathbf{S}$ & $\mathbf{T i}$ & $\mathbf{F e}$ \\
\hline $\mathbf{1 . 4 4 0 4}$ & 16.79 & 10.14 & 2.03 & 0.82 & 0.05 & 0.02 & 0.31 & 0.03 & 0.001 & - & balance \\
\hline $\mathbf{1 . 4 5 1 2}$ & $10.5 / 12.5$ & - & - & $<1$ & - & $<0.03$ & $<1$ & $<0.04$ & $<0,015$ & $\begin{array}{c}\text { Ti6x }(\mathrm{C}+\mathrm{N}) \\
\text { to } 0,65\end{array}$ & balance \\
\hline
\end{tabular}

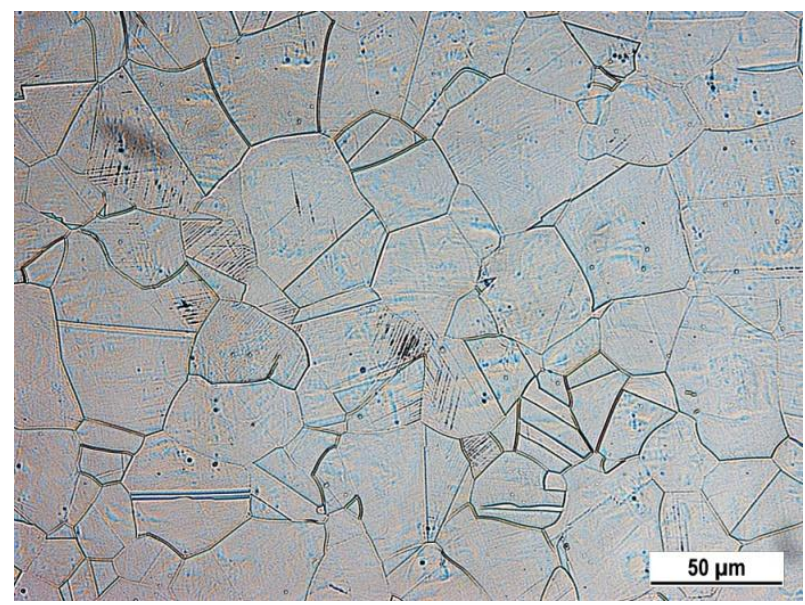

Fig. 1. Microstructure of 1.4404 stainless steel, cross section (Kallings etch.)

Microstructure of 1.4512 stainless steel in the central part of the cross section of metal sheet (fig. 2.) is created by ferrite where average of the grains size was 7,5 according to PN EN-ISO 643:2013-06. In the central part of the cross section of the metal sheet the grains of the ferrit are poligonalic, near the surfaces they are lightly elongated (PN EN-ISO 643).

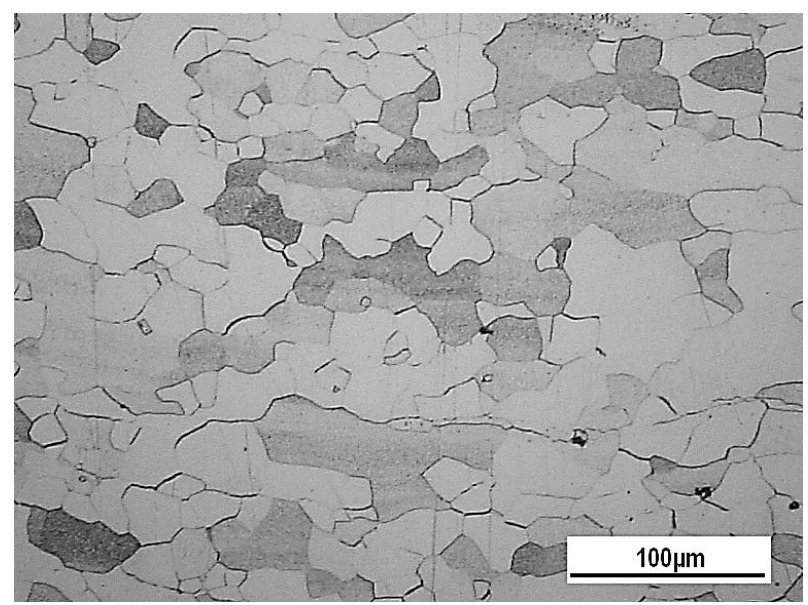

Fig. 2. Microstructure of 1.4512 stainless steel in the central part of the cross section of metal sheet (Nital etch.) 


\section{EXPERIMENTAL PROCEDURE}

Electrochemical corrosion test:

Cyclic potentiodynamic polarization tests (ASTM G61) of both stainless steels were carried out in a three electrode cell of corrosion measuring system (VoltaLab 10 with VSP unit). Potentiodynamic polarization curves were obtained by the EC-LAB SOFT software. Potential between the sample and the electrolyte has been settled for 10 minutes before the polarization. Scan range was $-0.2 \mathrm{~V}-0.9 \mathrm{~V}$ vs the open circuit potential and the scan rate was $1 \mathrm{mV} / \mathrm{s}$. The surface of working electrode (1.4404 and 1.4512 stainless steels) of $1 \mathrm{~cm}^{2}$ area was not additionally treated, only rinsed with ethanol before measurement. The saturated calomel electrode (SCE) was applied as the reference electrode and platinum foil as a counter electrode. All experiments were carried out at ambient temperature of $35^{\circ} \mathrm{C}$. At least five experiment repeats were carried out and one representative curve for both types of steels was chosen.

The $5 \%$ sodium chloride solution acidified by the acetic acid was used as the corrosion environment for electrochemical cyclic potentiodynamic test. The resulting $\mathrm{pH}$ of solution was 3.2 and the specific conductivity was $85.2 \mathrm{mS}^{-\mathrm{cm}^{-1}}$. The used solution was chosen because of simulation aggressive environment to which exhaust systems are exposed.

\section{Exposure immersion test:}

The pitting corrosion resistance of the both materials was also tested by ASTM G48 immersion test in $5 \%$ ferric chloride solution (Zatkalíková et al., 2014). The specimen's shape for the immersion test was rectangular $(30 \mathrm{~mm} \times 30 \mathrm{~mm})$. The specimen surface was not treated (mechanically or chemically) only the edges were ground by abrasive paper grain 600 . The grease was removed by ethanol. The specimens were weighted out with accuracy $\pm 0.00001 \mathrm{~g}$ (Mettler Toledo XS 205). Immersion test was 24 hours and it was carried out at the ambient temperature of 35 ${ }^{\circ} \mathrm{C}$. After exposure the specimens were carefully brushed, washed by de-mineralized water and by ethanol, freely dried up and weighted out again.

Specimen surfaces after immersion tests were observed by the optical microscope Axio Imager. Average corrosion rates $\left(\mathrm{g} \cdot \mathrm{m}^{-2} \cdot \mathrm{h}^{-1}\right)$ were calculated from the mass losses (g) during the immersion tests (two parallel specimens were tested for each steel type and the average corrosion rates were calculated).

\section{EXPERIMENT RESULTS AND DISCUSSION}

According to ASTM G61 standard method, the pitting potential $\left(E_{p}\right)$ and the repassivation potential $\left(E_{r p}\right)$ are the most important electrochemical characteristics of the cyclic potentiodynamic polarization curve. $E_{p}$ potential can be determined as the potential of a sudden, strong increase of current density on the curve of the direct measurement, which denotes the breakdown of the passive film and the beginning of stable pit growth. The shift of $E_{p}$ to more noble value means the rise of resistance to pitting (Szklarska-Smialowska, 2005), (Hadzima and Liptáková, 2008). $E_{r p}$ is obtained as the potential at which the backward measurement curve crosses the direct measurement curve.

The corrosion potential $\left(E_{\text {corr }}\right)$ and the corrosion curret density $\left(i_{\text {corr }}\right)$ are aelectrochemical characteristics which can be determined according to Tafel analysis of the potentiodynamic curve. The lower $E_{\text {corr }}$ points to the lower termodynamicstability 
of metal/alloy. The $i_{\text {corr }}$ value has the direct relationship to the kinetics of the corrosion process. The higher $i_{\text {corr }}$ value means the higher corrosion rate.

Cyclic potentiodynamic curves of the tested steels in $5 \%$ acidified sodium chloride solution are shown in Figs. 3. and 4. The electrochemical characteristics of the both steels are in Table 2.

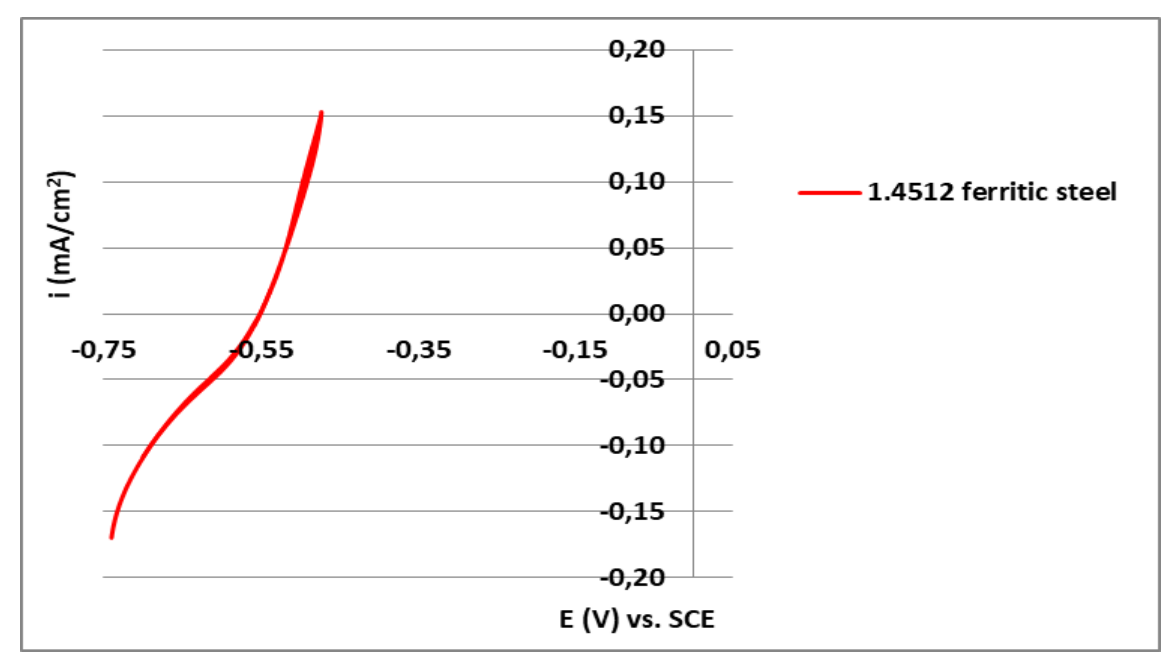

Fig. 3. Cyclic potentiodynamic curve of 1.4512 working electrode in $5 \% \mathrm{NaCl}$ acidified solution

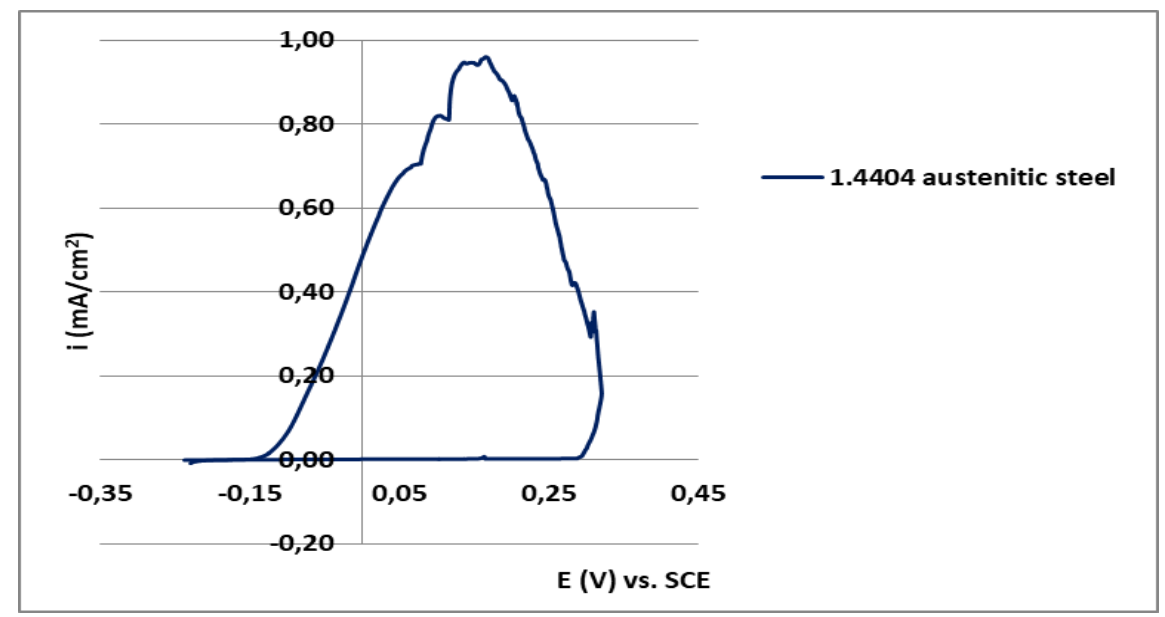

Fig. 4. Cyclic potentiodynamic curve of 1.4404 working electrode in $5 \% \mathrm{NaCl}$ acidified solution

Table 2

The electrochemical characteristics of the 1.4512 and 1.4404 stainless steels

\begin{tabular}{|l|l|l|l|l|}
\hline Material & $E_{p}(\mathrm{~V})$ & $E_{r p}(\mathrm{~V})$ & $E_{\text {corr }}(\mathrm{V})$ & $\boldsymbol{i}_{\text {corr }}\left(\boldsymbol{\mu \mathrm { A } / \mathrm { cm } ^ { 2 } )}\right.$ \\
\hline $\mathbf{1 . 4 5 1 2}$ austenitic steel & 0.287 & -0.154 & -0.120 & 0.08 \\
\hline $\mathbf{1 . 4 4 0 4}$ ferritic steel & - & - & -0.551 & 1.95 \\
\hline
\end{tabular}

The shape of 1.4512 ferritic steel cyclic polarization curve (Fig. 3) points to an active anodic dissolution in aggressive chloride environment. The surface passive film was probably broken at the start potential (-200 mV vs. open circuit potential). It became evident by increase of current density immediately after overreaching of its zero value. Therefore it was not possible to determine the $E_{p}$ and $E_{r p}$ potentials. 
The cyclic curve of 1.4404 austenitic steel (Fig. 4) is of a typical loop shape with clearly observable pitting potential (located in the point of the strong current density increase on the direct measurement curve).

All electrochemical characteristics presented in Table 2 indicate the significantly lower corrosion resistance of the ferritic steel in comparison with the austenitic one.

These results were confirmed by an independent ASTM G48 exposure immersion test as well. The surfaces of both steels were attacked by corrosion, but the damage is very different. The surface of the 1.4512 ferritic steel became dark and matte (Fig. 5A.). When observed with the naked eye, the damage is similar to uniform corrosion. Microscopic observation revealed small, round shaped corrosion pits uniformly distributed over the entire surface (Fig. 6.).

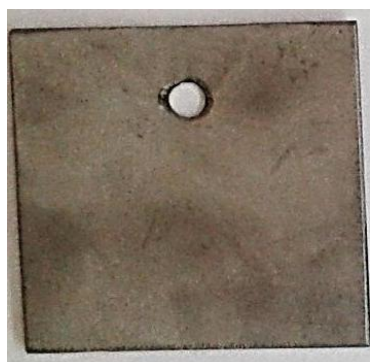

A

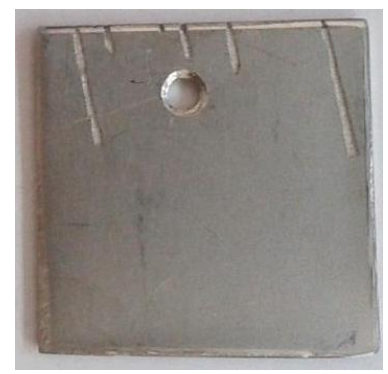

B

Fig. 5. Comparison of the steel surfaces after exposure immersion test: A) 1.4512 ferritic steel, B) 1.4404 austenitic steel
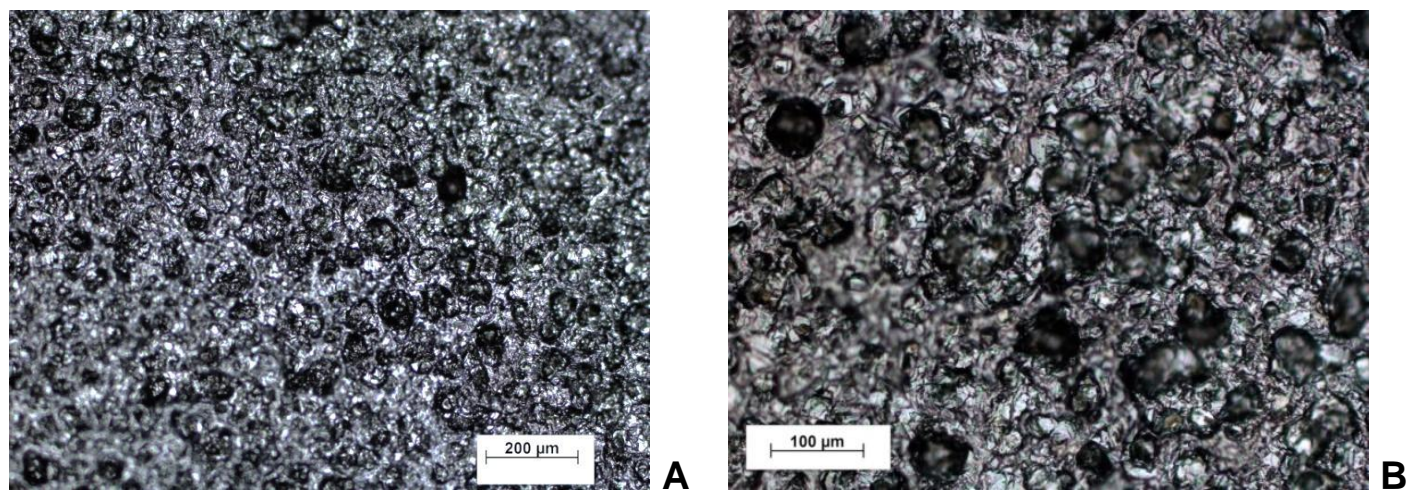

Fig. 6. The surface of 1.4512 steel after immersion test ( microscope Zeis Axio Imager A1m, foto AxioCam MR5)

The typical local corrosion damage of 1.4404 austenitic steel is shown in Fig. 5B. Corrosion pits are narrow and long, they were probably initiated in the edge with higher surface roughness (in comparison with specimen area). A wavy, jagged edge of the pit can be seen on microscopic observation (Fig. 7). 


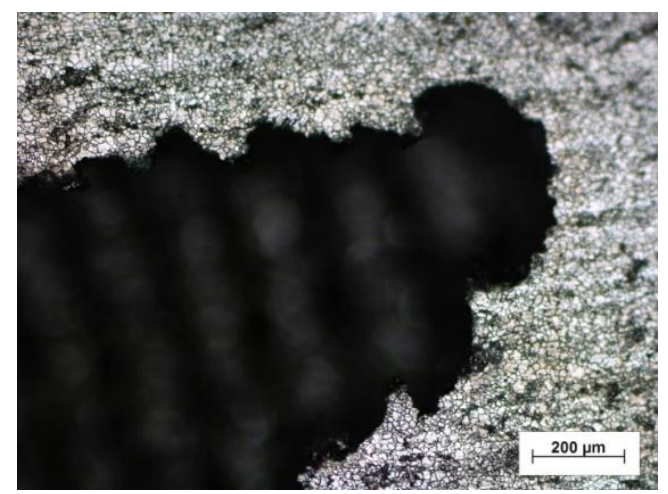

Fig. 7. Detail of corrosion pit on 1.4404 steel surface after immersion test(microscope Zeis Axio Imager A1m, foto AxioCam MR5)

Average corrosion rates calculated from mass losses during the immersion tests are shown and compared in Fig. 8. This comparison confirmed significantly higher corrosion resistance of 1.4404 austenitic stainless steel.

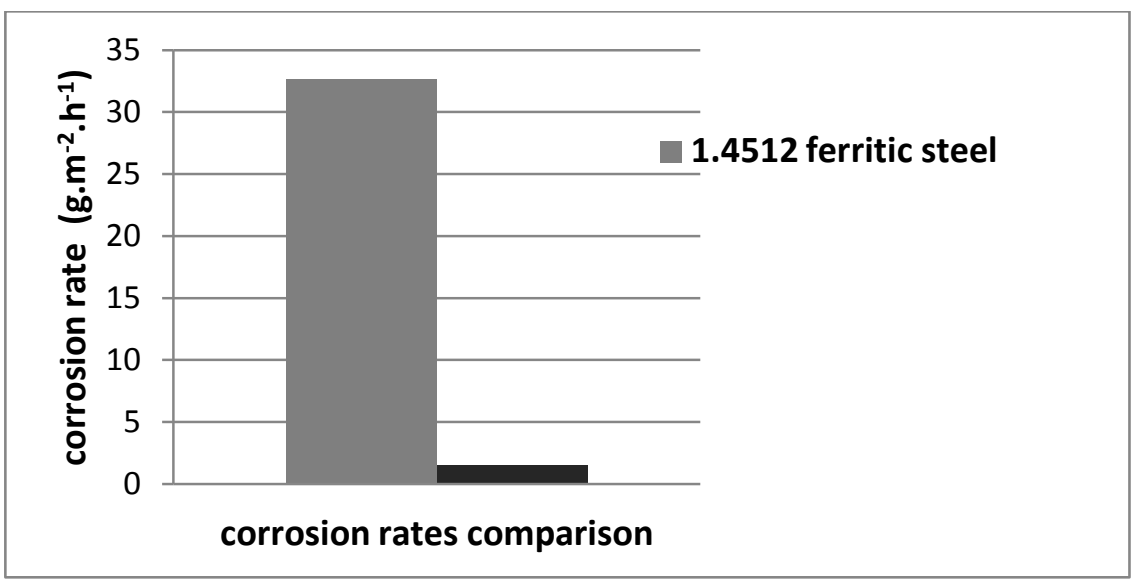

Fig. 8. The comparison of average corrosion rates calculated from mass loses during immersion test

\section{CONCLUSION}

In the above defined test conditions, both performed tests confirmed significantly better corrosion resistance of tested 1.4404 austenitic steel than of 1.4512 ferritic one. The sufficient corrosion resistance (required for exhaust systems) of 1.4512 steel is achieved by using Al-Si protective coatings which also essentially improve the aestetics of the product. The passive film formed on the coating surface is durable for the $\mathrm{pH}$ range of (4-8.5), as shown in the Pourbaix diagram (Wróbel-Knysak, 2012).

Due to the economic factor, 1.4512 ferritic steel is the most commonly used stainless steel with additionally applied protective coating. Due to the changing needs and requirements of the automotive market, exhaust materials are used individually for the model, class, and performance of the cars. Therefore, the use of 1.4404 steel is an excellent alternative for the individual needs of the consumer, for example, an aesthetic factor. Exhaust systems made of ferritic steel during operation (after the corrosion test) become matte, while the austenitic steel remains shiny.

Corrosion tests used at work do not include the effects of high temperatures, which in the exhaust systems is variable and reaches over $900{ }^{\circ} \mathrm{C}$, and it affects significantly corrosion processes, among others stress corrosion. 


\section{ACKNOWLEDGEMENTS}

The research was supported by Scientific Grant Agency of Ministry of Education, Science and Sport of Slovak Republic and Slovak Academy of Sciences, grant KEGA No. 049ŽU-4/2017.

\section{REFERENCES}

Adamczyk, J., 2004. Inżyniera materiałów metalowych. część 2. Wyd. Politechniki Śląskiej, Gliwice (in Polish).

Bala, H., 2002. Korozja materiałów - teoria i praktyka. Prace Dydaktyczne Wydziału Inżynierii Procesowej, Materiałowej i Fizyki Stosowanej, Seria: Inżynieria Materiałowa, Nr 5, Wyd. Politechniki Częstochowskiej, Częstochowa (in Polish).

Hadzima, B., Liptáková, T., 2008. Základy elektrochemickej korózie kovov (Fundamentals of electrochemical corrosion of metals). EDIS - Žilinská univerzita, Žilina (in Slovak).

Han, P.H., Xu, Z.H., Wang, C.P., Li, M.C., Bi, H.Y., 2014. Condensate corrosion behavior of type 409 stainless steel in simulated automotive muffler environments. International Journal of Elektrochemical Science 9, 3784-3794.

Inoue, Y., Kikuchi, M. 2003. Present and Future Trends of Stainless Steel for Automotive Exhaust System. Nippon Steel Technical Report 88, www.nssmc.com/en/tech/report/nsc/pdf/n8814.pdf.

Lukaszkowicz, K., 2014. Coatings for transport industry. Transport Problems, 9, 3, 1520.

PN EN-ISO 643:2013-06 Steel - Micrographic definition of grain size.

PN-EN 10088-2:2014-12 Corrosion resistant steel - Part 2: Technical conditions for the delivery of thin / thick sheets and stainless steel, general application

Rajadurai, S., Afnas, M., Ananth, S., Surendhar, S., 2014. Materials for automotive exhaust system. International Journal of Recent Development in Engineering and Technology, 2, 3, 82-89.

Szklarska - Smialowska, Z., 2005. Pitting and crevice corrosion. NACE International, Houston, Texas.

Uhríčik, M., Sapieta, M., Stankovičová, Z., Palček, P., Oravcová, M., 2016. The stress detection of stainless steel AISI 304, AISI 316L and AISI 316Ti during three-point bending cyclic loading. Materials Today proceedings 3, 4, on-line, 1189-1194.

Wróbel-Knysak, A., 2012. Increasing service life of Al-Si protective coatings used in the automotive industry. (PhD thesis, in Polish), Politechnika Częstochowska.

Wróbel-Knysak, A., Radziszewski, L., 2016. Condition of Al-Si protective coating of automotive exhaust systems after dip\&dry corrosion test. In: 33rd Interntional Colloqium, May 25-27 2016, Western Tatras - Zuberec, Slovakia, 116-119.

Wróbel, A., Kucharska, B., 2011. Materiały na elementy samochodowych układów wydechowych - dawniej i dziś. In: Materiały Konferencyjne nr 15, XII Międzynarodowej Konferencji Naukowej, Nowe Technologie i Osiągnięcia w Metalurgii i Inżynierii Materiałowej, Politechnika Częstochowska, 533-537 (in Polish).

Zatkalíková, V., Markovičová, L., Belan, J., Liptáková, T., 2014. Variability of local corrosion attack morphology of AISI 316Ti stainless steel in aggressive chloride environment. Manufacturing Technology, 14, 3, 493-497.

http://www.italinox.sk/ (accessed 12.4. 2018). 